\title{
Factors of Effective School Libraries: A Survey of Perspectives of Teachers, Teacher-librarians, and Principals
}

\section{MARLENE M. ASSELIN}

\author{
University of British Columbia, \\ Vancouver, Canada \\ marlene.asselin@ubc.ca
}

\begin{abstract}
This study assessed factors of effective school library programs in one school system. All teacher-librarians and principals and a sample of teachers in all public schools in an urban district were surveyed about a) background information of the teacher-librarians and school; b) library collection; c) library program; and d) issues facing the school library. Results of descriptive and correlational analyses indicate recent district-based initiatives to strengthen school libraries appear positive. Recommendations include increased leadership activities by teacher-librarians, advocacy targeted at principal education about school libraries, augmenting the number of teachers participating in substantive partnerships with teacher-librarians are recommended, and working toward a shared vision of the school library as the information center of the school.
\end{abstract}

\section{PURPOSE AND BACKGROUND OF THE STUDY}

This study sought to a) examine the degree to which factors of effective school library programs are in place in one school district and b) compare teachers', principals', and teacher-librarians' perceptions of the extent to which collaborative planning and teaching occur, the extent to which effective library programs are operating, and critical issues facing school libraries. Specific objectives of the study were to a) extend available provincial data about working and learning conditions in school libraries, b) identify focus areas of professional development and advocacy for the school district, and c) test the use of new measures that could be applied to studies of school libraries at the provincial and national levels.

School library programs have traditionally emphasized source location and retrieval skills along with promotion of the love of reading. New guidelines stress learning and teaching and the full integration of instructional technologies and information processes into school instructional programs (American Association of School Librarians and the Association for Educational Communications and Technology [AASL \& AECT] 1998; Association for Teacher-librarianship in Canada and the Canadian School Library Association [ATLC \& CSLA], 1997; International Federation of Library Associations and Institutions [IFLA], 2000). A growing body of literature identifies factors facilitating implementation of school library programs based on current guidelines. Major influences include hiring of qualified teacher-librarians; a strong leadership role by the teacherlibrarian; a flexible library schedule; strong principal support; high levels of collaborative planning, teaching, and evaluation; and shared knowledge between key players about the role of the teacher-librarian and school library program. These research-based principles are Inspiring connections: Learning, libraries \& literacy 
represented in position statements and policies of local, national, and international professional organizations.

\section{Teacher-librarian Qualifications}

While all professional organizations of school librarianship endorse hiring of qualified persons for teacher-librarian positions, what counts as qualified varies. AASL specifies that teacher-librarians have a liberal arts undergraduate degree, professional education certificate, and a masters' degree in the field. In Canada, two years of classroom teaching experience and "additional qualifications" rather than a graduate degree in teacherlibrarianship are designated entry requirements. Professional organizations and evidence from research also support hiring teacher-librarians for full time positions to ensure positive effects on student literacy achievement and self-esteem (Haycock, 1992). Finally, entry qualifications are just that, and teacher-librarians are expected to participate in ongoing professional development.

In many parts of Canada, people are hired for teacher-librarian positions as new or experienced teachers with no or very few additional qualifications in the field. Those working in elementary schools typically hold part-time positions reflecting provincial staffing ratio criteria.

\section{Leadership}

Leadership, along with collaboration and technology, are central components underlying the current vision of school library programs (AASL \& AECT, 1998). Strong leadership participation influences more effective use of library services and programs for supporting teaching and learning in the school (Crowley, 1995; Donham, 1997). Leadership activities include conducting workshops and serving on committees of technology and curriculum at school and district levels, and involvement in professional organizations especially in activities which disseminate information about the field.

\section{Library Schedule}

New guidelines view library programs as extensions of classroom curriculum. Research shows that school libraries with flexible schedules do more collaborative planning and teaching (Putnam, 1996; VanDuesen \& Talman, 1994). Frequent and active partnerships with teachers result in more opportunities for integrating information process instruction into the classroom curriculum. However, many teacher-librarians, especially those in elementary schools, are required to use substantial parts of their assignment to cover for teachers during their preparation time. During "teacher prep time," collaboration is not happening and opportunities for extending classroom curriculum and information literacy instruction are diminished.

\section{Principal Support}

There is an established and growing body of research showing the critical role of the principal in the development of effective school library programs (Haycock, 1992; Oberg, Hay \& Henri, 2001). Key support activities are provision of a budget to fully enable the program, and prioritizing time for collaborative planning and teaching to ensure maximum teaching and learning opportunities in the school library program. A recent multi-national 
study (Oberg et al., 2000) found that teacher-librarians have relatively low expectations for principals' support of their programs. In contrast, principals felt they should be doing more to support school libraries, especially in terms of facilitating collaborative planning and teaching, increasing library budget, and establishing a flexible schedule for the library. Lance, Welborn, \& Hamilton's (1993) finding of the direct influence of an adequately staffed library and a large library collection on student achievement point to the essential role of the principal in allocating sufficient funding for the school library.

\section{Collaboration}

There is a strong body of research indicating that development of student achievement and competence in information skills is more effective when integrated with classroom instruction through an equal planning and teaching partnership between classroom teacher and teacher-librarian (Hamilton-Pennell, Lance, Rodney, \& Hainer, 20000; Lance et al., 1993). Kuhlthau (1999) found that a high level of collaboration was one of two factors of increased student learning opportunities in school library programs. Collaboration between teachers and teacher-librarians is a major variable of implementing curriculumbased integrated school library programs such as AASL's Information Power (McCarthy (1997) and Library Power (Zweizig \& Hopkins, 1999). However, existing studies have found only low and moderate levels of collaborative curriculum planning, teaching, and evaluation between teachers and teacher-librarians (National Center for Education Statistics, 1994; Pickard, 1993).

\section{A Common Knowledge Base}

Current guidelines for school libraries are based on partnerships. Partnerships thrive when participants share common understandings about each other's role. Teacher-librarians' partners appear uneducated about the role of the teacher-librarian and the school library program. Recent studies show that both preservice and inservice teachers continue to have little knowledge or misconstrued ideas about the role of the teacher-librarian and school library program (Asselin, 2001; Moore, 2000; VanDuesen, 1996). Principals feel untrained about the place of school libraries in their schools (Wilson, Blake, \& Lyders, 1999) consequently unable to support them effectively. Even teacher-librarians themselves need to increase their understanding of their role (Haycock, 1992) as it shifts and grows.

\section{METHODOLOGY}

This study was designed as a pilot for a larger provincial study. Three versions of a survey were constructed to analyze perspectives of major stakeholders in school librariesschool principals, classroom teachers, and teacher-librarians. The pilot study was conducted in all schools in one district located within a large metropolitan area of western Canada. Data were collected in June 2000.

\section{Research Sample: The School District}

The school district that participated in this study consists of 71 elementary (grades $\mathrm{K}-5$ ), middle (grades $6-9$ ), and secondary (grades $10-12$ ) schools. One of the fastest growing districts in the province, enrolment has increased from 9116 in 1991 to 13,528 in 1999 (last year for which this data is available). Median income for the district is slightly 
above that of the province and percent of lower income families is slightly below the provincial average. The larger urban area in which this district is located has seen a dramatic increase in immigrant populations and ESL (English as a second language) programs in schools. However, the rate of change in this district is moderate compared to neighboring districts. Seventeen percent of the district's population uses a non-English language at home and $18 \%$ of the district's students participate in ESL programs. In contrast, $36 \%$ of a neighboring district's population uses a non-English language at home and $51 \%$ of the students participate in ESL programs.

The district is completing a five-year restructuring of the system and has become one of the few districts in the province to include middle schools. New schools have been built or existing ones remodeled to support this plan. Libraries in these new facilities are centrally located and equipped to maximize use of technological resources.

The district had hired a library coordinator two years before this study was conducted and this person had initiated a professional development program including on-site diploma courses and frequent inservice sessions.

\section{Data Collection}

Within each of the 71 schools in the district, three groups of educators were surveyed: teacher-librarian, principal, and teachers. Data collection was planned for early spring, approximately two months before end of the school year. However, complications at the district level outside of this study delayed data collection until the last month of school. Response rate from each of the three groups was as follows: 53 teacher-librarians (this represents all teacher-librarians in the district as several work in two elementary schools), 114 teachers, and 41 principals for an overall response rate of $58 \%$.

\section{$\underline{\text { Research Instrument }}$}

The instrument was collaboratively developed by the researcher and members of the provincial teacher-librarian association. Twelve schools (six elementary and six secondary) in a large urban area of the province were approached and asked to complete and comment on a questionnaire about school library programs and services. The principal, teacherlibrarian and one teacher from each school carried out this request and questionnaires were then revised based on examination of item response frequency distributions and comments concerning need for revision of any items.

Main sections of the final questionnaire were a) background information about the teacher, teacher-librarian, and school; b) library collection; c) library program including schedule, teacher usages, and activities and services; and d) library issues. Items represent effectiveness variables identified in the school librarianship as well as professional competencies described in Canada's national document (ACTL \& CSLA, 1998). Each questionnaire contains a different number of questions consisting of both Likert-scale and forced choice items. The number of questions per questionnaire is as follows: teacherlibrarian questionnaire, 38; principal, 30; teacher, 6. 


\section{Data Analysis}

To date, survey data has been analyzed using descriptive and correlational statistics at the group and instructional level $(\mathrm{K}-5,6-9,10-12)$. Some composite variables from questions containing multiple items were conceptually created to capture the underlying groupings of the items. For example, in the question about teacher uses of the library program and services, which consisted of items representing Loerstcher's (1988) taxonomy of collaboration, items were grouped into two variables-High Collaboration and Low Collaboration.

\section{RESULTS}

This paper reports analyses of background measures of the teacher-librarian (qualifications and hiring); teacher-librarian leadership; principal background (support activities); teacher usages of the library (collaboration); and comparative perspectives of school library issues and implementation level of school library programs.

\section{Teacher-librarian Background: Qualifications and Hiring}

This section reports information on several aspects of teacher-librarians' background including education, teaching and teacher-librarian experience, hiring policies, and employment status.

Teacher-librarian education. Insight into teacher-librarian education was gained by examining university education in the discipline and attendance at in-service events. Table 1 displays the range of type and amount of university education and inservice education in teacher-librarianship held by those with teacher-librarian positions in the district.

\section{Table 1}

Teacher-librarian Education: University degrees and Inservice Professional Development

\begin{tabular}{|c|c|c|}
\hline Type of Education & $\underline{\mathrm{N}}$ & $\underline{\%}$ \\
\hline \multicolumn{3}{|l|}{ University Programs } \\
\hline Masters & 5 & 9 \\
\hline Diploma $^{a}$ in Tlship completed & 17 & 36 \\
\hline Diploma partial $^{b}$ & 10 & 31 \\
\hline \multicolumn{3}{|c|}{ Attendance of Professional Inservice Programs $s^{c}$} \\
\hline 4 events or more & 40 & 85 \\
\hline 9 events or more & 17 & 36 \\
\hline
\end{tabular}

Across the district, $36 \%$ of the teacher-librarians had earned a diploma (30 credits or 10 courses) and 12\% held Masters' degrees in either teacher-librarianship (from Faculty of Education) or library science. Another $31 \%$ had completed six to nine of the required ten courses for a diploma in teacher-librarianship. Eighty-five percent have participated in four 
or more inservice professional development events over the last three years; of those teacherlibrarians, $36 \%$ had participated nine or more times.

Hiring policies; Teacher-librarian education and teaching experience. Principals reported a range of minimal qualifications in teacher-librarianship courses (zero to 10) and number of years teaching experience (zero to 4) required for hiring. They also reported inconsistent hiring standards at both their school and district level. For example, $90 \%$ of principals reported that the district required no teaching experience, while only $33 \%$ would hire someone for an appointment in their school with no teaching experience and $28 \%$ looked for a minimum of two years. Tables 2 and 3 summarize school and district hiring policies reported by school principals.

Table 2

Teacher-librarian Hiring Policies by District and School: Teaching Experience

\begin{tabular}{lrrrrr}
\hline & \multicolumn{2}{c}{ District } & & \multicolumn{2}{c}{ School } \\
\cline { 2 - 3 } \cline { 5 - 6 } Years of Experience & $\underline{\mathrm{N}}$ & $\underline{\%}$ & & $\underline{\mathrm{N}}$ & $\%$ \\
\hline 0 & 32 & 90 & 12 & 33 \\
1 & 3 & 8 & & 5 & 14 \\
2 & & & 9 & 25 \\
3 & & & 5 & 14 \\
4 & 1 & 2 & 5 & 14 \\
\hline
\end{tabular}

Table 3

Teacher-librarian Hiring Policies by District and School: Teacher-librarian Education

\begin{tabular}{lrrrrr}
\hline & \multicolumn{2}{c}{ District } & & \multicolumn{2}{c}{ School } \\
\cline { 2 - 3 } Minimum Number of Courses & $\underline{N}$ & $\%$ & & $\underline{N}$ & $\%$ \\
\hline 0 & 4 & 11 & 1 & 3 \\
$1-3$ & 18 & 51 & 15 & 40 \\
$4-6$ & 3 & 9 & 8 & 22 \\
$7-9$ & 1 & 3 & 2 & 5 \\
Diploma (10) & 9 & 26 & 11 & 30 \\
\hline
\end{tabular}

Teaching and Teacher-librarian Experience. While all teacher-librarians had been practicing teachers for at least one year, $70 \%$ had been teaching ten or more years while $13 \%$ were new teachers ( $1-3$ years). However, more than one-third $(38 \%)$ were new to the position of teacher-librarian ( 1 - 3 years) and another one-third had been practicing as teacher-librarians for ten or more years. Additionally, $70 \%$ were new to their current position while only $8 \%$ had been in the same position for ten or more years. Table 4 presents findings about the teaching and teacher-librarian experience. 


\section{Table 4}

Teacher-librarian Experience in Teaching and Teacher-librarianship

\begin{tabular}{lrrrrrrrr}
\hline & \multicolumn{2}{c}{ Teaching } & & \multicolumn{2}{c}{ Tlship } & & \multicolumn{2}{c}{ Current Position } \\
\cline { 2 - 5 } \cline { 7 - 9 } Years Experience & $\underline{N}$ & $\underline{\%}$ & & $\underline{N}$ & $\underline{\%}$ & & $\underline{N}$ & $\underline{\%}$ \\
\hline $1-3$ years & 6 & 13 & 18 & 38 & & 33 & 70 \\
$4-6$ & 7 & 15 & 7 & 15 & & 9 & 19 \\
$7-9$ & 1 & 2 & 5 & 10 & & 1 & 2 \\
$>9$ & 33 & 70 & 17 & 36 & & 4 & 8 \\
\hline
\end{tabular}

Employment Status. While more than half of the teacher-librarians (57\%) were employed full time in one school, only $34 \%$ were employed full time as teacher-librarians. Approximately half (51\%) were employed as teacher-librarians between $50-99 \%$ of their assignment and $15 \%$ were employed less than half-time as teacher-librarians. Table 5 displays data about teacher-librarians' employment time and assignment responsibilities both in the library and in the school.

\section{Table 5}

Appointment Assignment: Time as Teacher-librarian and Other Responsibilities

\begin{tabular}{ccc}
\hline Time & $\underline{N}$ & $\underline{\%}$ \\
\hline Assignment as teacher-librarian & & \\
$25 \%-49 \%$ & 7 & 15 \\
$50 \%-74 \%$ & 13 & 28 \\
$75 \%-99 \%$ & 11 & 23 \\
$100 \%$ & 16 & 34
\end{tabular}

Other assignment

Classroom teacher

Computer teacher

11223

Teacher of gifted

Learning assistance

$\mathrm{ESL}^{\mathrm{a}}$ teacher

Other

$\begin{array}{rr}6 & 13 \\ 4 & 8\end{array}$

$5 \quad 11$

Note: Time refers to assignment in one school. ${ }^{a}$ English as a second language.

\section{Leadership}

Leadership was assessed by examining if teacher-librarians held department leadership positions in their schools, extent of involvement in school and district technology plan implement-ation, level of competence with technology, and participation in professional activities. Table 6 shows types of and degree to which teacher-librarians in the district assumed leadership roles at school, district, and professional organization levels. 
Table 6

Teacher-librarian Leadership: Department Head, Role in Technology Plan Implementation, Technology Competency, and Involvement in Professional $\underline{\text { Activities }}$

\begin{tabular}{lrr}
\hline Leadership Activity & $\underline{N}$ & \% \\
\hline $\begin{array}{l}\text { Serve as department heads or team leaders } \\
\text { Involvement in technology plans }\end{array}$ & 7 & 15 \\
$\quad$ School & & \\
$\quad$ High or very high & 17 & 36 \\
$\quad$ No or very low & 11 & 23 \\
$\quad$ Histrict & 3 & 6 \\
$\quad$ High & 30 & 54 \\
$\quad$ & 11 & 23 \\
$\quad$ NL or very low & 26 & 76 \\
$\quad$ Average & 16 & 41 \\
$\quad$ Pbove average and very high & 23 & 59 \\
$\quad$ Below average and average & & \\
$\quad$ Above average and very high & 34 & 72 \\
Involvement in Professional Activities: & 29 & 62 \\
Chair or serve on school committee & 22 & 47 \\
Initiate or participate in school-based projects & 17 & 36 \\
Provide workshops for teachers/teacher-librarians & 12 & 26 \\
Work as a volunteer & 10 & 21 \\
Engage in advocacy work & 3 & 6 \\
Hold office in professional organization & & \\
Review resources for professional publications & & \\
Contribute regularly to professional publications & & \\
\hline
\end{tabular}

Fifteen percent of the teacher-librarians were department heads or team leaders in their schools, $36 \%$ were actively involved in implementing their school technology plan, while $16 \%$ led implementation of the district technology plan. When asked to rate their own abilities to use technology to locate and evaluate information, nearly three-quarters (76\%) of teacher-librarians indicated above average or very high. In contrast, only $15 \%$ of principals rated their abilities as very high and $44 \%$ as above average.

The majority of teacher-librarians chaired or served on school committees and participated or initiated school-based special projects. Nearly half provided workshops for colleagues. Working as a volunteer, engaging in advocacy work, and holding office in a professional organization were activities reported by fewer respondents-36\%, 26\%, and $21 \%$ respectively. Very few teacher-librarians reviewed materials $(6 \%)$ or published $(4 \%)$ in professional publications. 


\section{Principal Support}

Table 7 identifies activities that principals reported they used to support the school library.

\section{Table 7}

Principal Support Activities for School Library

\begin{tabular}{lrr}
\hline Activity & $\underline{N}$ & $\underline{\%}$ \\
\hline Hold regular planning sessions about school library & 5 & 13 \\
Provide CPPT time (more than 50\% of TL's time) & 7 & 17 \\
Provide extra funds in budget & 16 & 41 \\
Keep flexible library schedule & 24 & 62 \\
Support publicity about library & 31 & 80 \\
Provide time at staff meetings & 34 & 87 \\
Elicit support from parent association & 36 & 92 \\
\hline
\end{tabular}

The activities have been listed hierarchically with those at the top representing the most direct and effective methods and those at the bottom reflecting indirect and less effective ways. While most principals supported school libraries with traditional means, a small minority used more direct methods. Major factors of principal support are providing an enabling budget and time for collaborative planning. Findings about these factors are reported below.

Library Budget. Across all schools, principals reported that percentage of library budget to rest of school budget was 11.67. Fifty-three percent of principals reported that the budget for the school library represented $10 \%$ or less of the entire school budget. In thirtytwo percent of schools, $11-19 \%$ of the school budget was allocated for the school library. In only one school was the budget for the school library over $20 \%$ of the school budget at $25 \%$. Principals also reported amount of money per pupil for the library collection. Table 8 lists means and standard deviations of school library budget by school level.

Table 8

School Library Budget by District and by School Level

\begin{tabular}{lccccc}
\hline \multirow{2}{*}{ School Level } & \multicolumn{2}{c}{ \% School Budget } & & \multicolumn{2}{c}{ S/pupil } \\
\cline { 2 - 3 } \cline { 5 - 6 } & $\underline{M}$ & $\underline{\text { SD })}$ & & $\underline{M}$ & $\underline{(S D)}$ \\
\hline District & 11.67 & $(5.67)$ & & 14.48 & $(10.43)$ \\
Elementary & 11.48 & $(6.03)$ & & 14.29 & $(11.46)$ \\
Middle & 13.00 & $(5.66)$ & & 12.70 & $(3.38)$ \\
Secondary & 10.67 & $(1.15)$ & & 21.00 & $(12.73)$ \\
\hline
\end{tabular}


Library Schedules and Providing Prep Time. The principal plays a critical role in determining how teacher-librarians spend their time. While most teacher-librarians in the middle $(82 \%)$ and secondary schools $(100 \%)$ operated a flexible schedule, only $6 \%$ of elementary libraries had flexible schedules, with $38 \%$ using a fixed schedule, and $41 \%$ using a modified flexible schedule. Table 9 displays library schedules in elementary, middle, and secondary schools.

\section{Table 9}

\section{Library Schedule by School Level}

\begin{tabular}{|c|c|c|c|c|c|c|}
\hline \multirow[b]{3}{*}{ School Level } & & \multicolumn{5}{|c|}{ Type of Schedule } \\
\hline & \multicolumn{2}{|c|}{ Fixed } & \multicolumn{2}{|c|}{ Flexible } & \multicolumn{2}{|c|}{ Mod. Flex } \\
\hline & $\underline{N}$ & $\%$ & $\underline{\mathrm{N}}$ & \% & $\underline{N}$ & $\%$ \\
\hline$K-5$ & 12 & 38 & 2 & 6 & 13 & 41 \\
\hline $6-9$ & 0 & 0 & 9 & 81 & 2 & 13 \\
\hline $10-12$ & 0 & 0 & 5 & 100 & 0 & 0 \\
\hline
\end{tabular}

Note: Percentage refers to percentage within grade level.

All but two elementary teacher-librarians provided some relief time for teachers as part of their job. Half of these teacher-librarians used more than half their time providing relief time while those working in middle and secondary schools did not commit any time to teacher release time.

\section{Teachers' and Teacher-librarians' Collaborative Uses of the School Library}

Items in this section were based on Loertscher's taxonomy of collaboration. Table 10 shows how teachers and teacher-librarians reported that most teachers in their schools collaborated with teacher-librarians to support teaching and learning in the school.

Table 10

Level of Collaboration between Teachers and Teacher-librarians

\begin{tabular}{|c|c|c|c|c|c|c|c|c|}
\hline \multirow[b]{3}{*}{ Group } & \multicolumn{4}{|c|}{ High } & \multicolumn{4}{|c|}{ Low } \\
\hline & \multicolumn{2}{|c|}{ 2-3/term } & \multicolumn{2}{|c|}{ 2-3/year } & \multicolumn{2}{|c|}{ 2-3/term } & \multicolumn{2}{|c|}{ 2-3year } \\
\hline & $\mathrm{N}$ & $\%$ & $\mathrm{~N}$ & $\%$ & $\mathrm{~N}$ & $\%$ & $\mathrm{~N}$ & $\%$ \\
\hline Teacher & 22 & 19 & 22 & 19 & 71 & 62 & 43 & 38 \\
\hline TL & 13 & 25 & 9 & 17 & 31 & 60 & 16 & 30 \\
\hline
\end{tabular}

Note: High Collaboration $=$ Plan and teach units with the teacher-librarian, Plan lessons with the teacher-librarian, Work with the teacher-librarian to implement curricular change, Teach information literacy skills with the teacher-librarian, Work with the teacher-librarian to evaluate collaboratively planned and taught lessons/units. Get teaching ideas and suggestions for materials from the teacherlibrarian.

Low Collaboration $=$ Supplement classroom instructional materials, Schedule book exchanges for classes, Send students to library to find information, Independently select resources from the library, Borrow library material materials for instructional use in classrooms. 
At the higher levels, $19 \%$ of teachers and $25 \%$ of teacher-librarians reported regularly working together in that way. At the lower end, $62 \%$ of teachers and $60 \%$ of teacher-librarians reported most teachers and teacher-librarians collaborate this way most often.

\section{Implementation of School Library Program}

All groups of educators responded to 17 statements about the degree to which various components of the school library program, as identified by the provincial and national associations of teacher-librarians, were actually in place in their schools. Table 11 lists percentages of each group (principals, teachers, teacher-librarians) that perceived the program fully and minimally in place.

\section{Table 11}

Implementation of School Library Program

\begin{tabular}{lrrrr}
\hline \multirow{2}{*}{ Group } & \multicolumn{3}{c}{ Extent of Implementation } \\
\cline { 2 - 5 } & \multicolumn{2}{c}{ Full } & \multicolumn{2}{c}{ Minimal } \\
\cline { 2 - 5 } & $\mathrm{N}$ & $\%$ & $\mathrm{~N}$ & $\%$ \\
\hline Teacher-librarian & 22 & 46 & 18 & 0 \\
Teacher & 42 & 37 & 3 & 7 \\
Principal & 14 & 35 & 36 \\
\hline
\end{tabular}

Teachers, teacher-librarians, and principals held statistically significant different perceptions of the degree to which three particular aspects of their school library program were in place: that the school library is the information center of the school, that a major responsibility of the teacher-librarian is to consult with teachers about supporting their learning objectives, and that the library program models and supports collaborative planning. Table 12 reports results of Analyses of Variance of the three significant items.

\section{Table 12}

ANOVA for Aspects of School Library Programs Differentially Perceived to be in Place by Teachers, Teacher-librarians, and Principals

\begin{tabular}{lccc}
\hline Program Aspect & $\underline{\mathrm{F}}$ & $\underline{\mathrm{df}}$ & $\underline{\mathrm{p}}$ \\
\hline Library as school information center & 4.14 & 202 & .01 \\
Consult with teachers about learning objectives & 4.24 & 201 & .01 \\
Model and support collaborative planning & 3.82 & 200 & .02 \\
$\mathrm{p}<.05$ & & & \\
\hline
\end{tabular}

A separate question focused on information literacy instruction. More than threequarters of teacher-librarians and principals reported that an information literacy continuum was in place in their school. All cited the source of this continuum as district-developed (Bens et al., 1999). Across kindergarten through grade 9, at least $70 \%$ of teacher-librarians taught information literacy skills to students once a month or more. 


\section{$\underline{\text { School Library Issues }}$}

Principals and teacher-librarians rated the importance of seven issues facing the school library. As seen in Table 13, teacher-librarians and principals agreed the relative importance of all issues except one - the importance of provincial standards of staffing and funding for school libraries.

\section{Table 13}

School Library Issues: Perspectives of Principals and Teacher-librarians

\begin{tabular}{|c|c|c|c|c|}
\hline \multirow[b]{2}{*}{ Issue } & \multicolumn{2}{|c|}{ Rated Very Important } & \multicolumn{2}{|c|}{ Mean (SD) } \\
\hline & $\underline{\mathrm{P}}$ & $\underline{\mathrm{TL}}$ & $\underline{\mathrm{P}}$ & $\underline{\mathrm{TL}}$ \\
\hline Promote literacy & 90 & 87 & $3.95(.22)$ & $3.87(.33)$ \\
\hline $\begin{array}{c}\text { Provide physical and intellectual } \\
\text { access to information }\end{array}$ & 70 & 68 & $3.66(.53)$ & $3.60(.68)$ \\
\hline Leadership in information tech & 56 & 64 & $3.59(.50)$ & $3.58(.65)$ \\
\hline $\begin{array}{l}\text { Ensure equity and freedom of } \\
\text { access to information }\end{array}$ & 54 & 53 & $3.54(.54)$ & $3.40(.82)$ \\
\hline $\begin{array}{l}\text { Participate in resource access } \\
\text { networks }\end{array}$ & 28 & 30 & $3 / 15(.63)$ & $3.06(.76)$ \\
\hline $\begin{array}{l}\text { Provincial information literacy } \\
\text { Standard }\end{array}$ & 15 & 34 & $2.80(.76)$ & $2.98(.93)$ \\
\hline $\begin{array}{l}\text { Provincial standards for funding } \\
\text { and staffing }\end{array}$ & 13 & 75 & $.53(.91)$ & $3.65(.67)$ \\
\hline
\end{tabular}

\section{DISCUSSION}

This section interprets findings about teacher-librarian qualifications and hiring; teacher-librarian leadership; principal support; collaboration between teachers and teacherlibrarians; and comparative perspectives of implementation levels of school library programs and school library issues.

\section{Teacher-librarian Qualifications}

Seventy-eight percent of teacher-librarians in this district are qualified according to standards recommended by the provincial teacher-librarian association exceeding the provincial average of $60 \%$ for both elementary and secondary levels. However, only $11 \%$ meet entry standards set by AASL, an influential organization in Canada. Teacher-librarians in the district are moderately active in pursuing professional development averaging slightly more than one inservice program per year. Results suggest that efforts by the recently hired library coordinator to increase staff qualifications through access to university courses in the field and to provide more opportunities for professional development are working. However, the goal of $100 \%$ qualification should continue to be pursued. 
Within the district, hiring policies based on teacher-librarian education and teaching experience are inconsistent across schools and between the district and individual schools. Principals report higher standards for teacher-librarian education requirements than what they think the district requires. Just over half the principals adhere to the profession's recommendations for a minimum of two years of teaching experience. At the district level, no teaching experience appears to be required. Finally, only about one-third of the district's teacher-librarians held full time positions thus jeopardizing full integration of the school curriculum and school library program as recommended by professional organizations. While part-time teacher-librarians also held other teaching positions, most of these were as classroom teacher followed by special subject teachers. Taken together, findings about teacher-librarian qualifications and hiring indicate the need for consistent standards between schools and at the district level and continued advocacy for meeting minimum qualification and FTE standards set by the provincial teacher-librarian organization.

\section{Teacher-librarian Leadership}

While teacher-librarians in this district participate as leaders in some school-based activities, they are much less involved in district initiatives or professional organizations. This likely reflects the high percentage of new teacher-librarians in the district and the principle that local contexts are a logical starting place for developing leadership. That more teacher-librarians have higher levels of technological competencies than principals suggests that teacher-librarians should take leadership roles in this area in their schools. Schools where teacher-librarians are strong leaders likely provide more effective programs and services (Crowley, 1995; Donham, 1997). Given the centrality of advocacy efforts in teacher-librarianship, it is surprising that only about one-quarter of the profession participates in these activities. Teacher-librarians in the district need to expand their sphere of influence from local to district and beyond to increase visibility and credibility of their contributions to education.

\section{Principal Support}

While all types of support methods are important, it is distressing that few principals provide time for collaboration between teachers and teacher-librarians or build in regular planning time about the school library. The $41 \%$ of schools where principals attempted to provide extra funds for the library likely have more adequate staffing and collections to support the curriculum. Judging from teacher-librarians' reports of their library schedules, it is also likely that most of the principals who reported they keep flexible library schedules represent middle and elementary schools, and that principals' interpretations of flexible schedules include modified flexible schedule. School libraries with fixed schedules are a concern as such a structure makes it difficult to embed the school library in the schools' instructional programs. Finally, it is disturbing that the district level library budget, while close to the provincial average, represents widely varying amounts suggesting extreme inequities between schools. Findings about principal support activities confirm the need for more principals to be doing more to support their school library programs. The many new teacher-librarians in the district will need guidance in learning how to encourage their principals to be effective co-leaders in the school library program (Oberg, 1996). A major part of this work will be educating principals about something they are coming to realize they know little about-school libraries (Oberg et al., 2000; Wilson et al., 1999). 


\section{Collaboration}

At first glance, findings about the type and degree of collaboration between teachers and teacher-librarians are disconcerting suggesting generally low amounts of meaningful learning opportunities for students in the school library (Kuhthlau, 1999; Lance et al., 1993). Nearly three-quarters of teachers most frequently use the school library at Loerschter's lower levels of collaboration, while less than one-quarter frequently collaborate at the higher levels indicating agreement with other findings of generally low to moderate levels of instructional partnerships (National Center for Educational Statistics, 1994; Pickard, 1993). However, the higher levels of collaboration are more time-consuming to plan, teach, and evaluate therefore reducing the frequency this can realistically be carried out over a year. Results show that despite the benefits of student learning, a minority of teachers participate in substantive collaboration. It is noteworthy that teachers and teacher-librarians perceive similar amounts of high and low collaborative uses of the school library.

Implementation of the School Library Program and School Library Issues: Comparative Perspectives

While it is not surprising that more teacher-librarians viewed their programs more highly than teachers and principals, it is interesting that less than half of the teacherlibrarians felt all aspects of their program were fully in place. This could speak to the high level of expectation outlined by the profession as well as to the relatively high numbers of new teacher-librarians. It is encouraging that no teacher-librarians saw their program as weak and only a very few principals and teachers did. It is a concern but not unexpected (Moore, 2000; VanDuesen, 1996) that the three groups have significantly different perceptions of three central principles of the school library program-that it is the information center of the school, and that collaboration with teachers is strongly in place. These results suggest increased efforts at the district level to strengthen the vision of the school library as central to supporting teaching and learning and more modeling and advocacy about the benefits of collaborative planning and teaching.

That teacher-librarians and principals agreed about the importance of six of seven issues facing school libraries indicates a fair amount of shared knowledge and therefore a basis for working together. Results show that teacher-librarians in the district need to target some of their advocacy efforts with principals about the importance of establishing provincial standards for funding and staffing. Principal support of these standards would likely have significant influence on enabling effective programs (Lance et al., 1993).

In light of the above three analyses about multiple perspectives on collaboration between teachers and teacher-librarians, implementation of the school library program, and school library issues, it is interesting to note that $70 \%$ of the teacher-librarians reported that the teachers they work with are either uninformed or somewhat informed about the role of the teacher-librarian and school library program.

\section{CONCLUSIONS AND IMPLICATIONS}

Findings from this study suggest that professional development efforts by the district are productive. Collaborative planning and teaching, information literacy instruction, and school library program implementation are evident to some degree to all three groups of 
educators. However, structural and cultural conditions need to improve to ensure districtwide effects. The district teacher-librarian association has established an advocacy committee in response to the need to gain principals' more direct support and more teachers as informed instructional partners. In light of the findings from this study, the district continues to increase professionalization of teacher-librarians such as through granting educational leaves to pursue master degrees. Although a third of teachers see their library programs as fully supporting teaching and learning in their schools, that percentage needs to increase so that all teachers and principals see the school library as the information center of the school and an inspiring place for teaching and learning. Finally, the information yielded by this pilot study needs to be extended to the provincial, national, and international level to establish a comparative data base of factors of effective school library programs and benchmarks towards realizing national and international guidelines (AASL \& AECT, 1998; ATLC \& CSLA, 1997; IFLA, 2000). With a larger data base, investigations of interactions among factors, between factors and library program implementation, and between factors and perspectives of multiple participants in the school library can be conducted with more validity than existing data permits.

\section{REFERENCES}

American Association of School Librarians and the Association for Educational Communications and Technology (1998). Information power: Building partnerships for learning. Chicago: American Library Association.

Asselin, M. (2000). Poised for change: Effects of a teacher education project on pre-service teachers' knowledge of the school library program and the role of the teacher-librarian. School Libraries Worldwide, 6 (2), 72-88.

Association for Teacher-librarianship in Canada and the Canadian School Library Association (1997). Students' information literacy needs: Competencies for teacherlibrarians in the 21st Century. [On-line] Available: http://www.cla.ca/divisions/csla/ pub 2.htm [2001, March 6].

Bens, S. et al. (1999). Learning outcomes for information literacy. Coquitlam: School District \#43. [On-line] Available: http://www.library.ubc.ca/edlib/Learning.html [2001, Jan. 8].

Crowley, J. (1995). A leadership role for library media specialists. School Library Media Annual, 13, 60-65.

Donham, J. (1997). Enhancing teaching and learning: A leadership guide for school library media specialists. New York: Neal Schuman.

Hamilton-Pennell, C., Lance, K., Rodney, M., Hainer, E. (2000). Dick and Jane Go to the Head Of the Class. School Libraries Journal Online. Available: http://www.sli.com/articles/ articles/20000401 7475.asp [2001, March 6].

Haycock, K. (1992). What works: Research about teaching and learning through the school library center. Seattle, WA: Rockland.

International Federation of Library Associations and Institutions (2000). The school library in teaching and learning for all: IFLA/UNESCO school library manifesto. [On-line] Available: www.ifla.org [2001, February 3].

Kuhlthau, C. C. (1999). Student learning in the library: What library power librarians say. School Libraries Worldwide, 5, 80-96.

Lance, K. C., Welborn, L., \& Hamilton-Pennell, C. (1993). The impact of school library media centers on academic achievement. Castle Rock, CO: Willow Research and Publishing. 
Loertscher, D. L. (1988). Taxonomies of the school library media program. Englewood, $\mathrm{CO}$ : Libraries Unlimited.

McCarthy, C. A. (1997). A reality check: The challenges of implementing information power in school library media programs. School Library Media Quarterly, 15, 205-214.

Moore, P. (2000). Primary school childrens' interaction with library media: Information literacy in practice. Teacher-Librarian, 27 (3), 7-11.

National Center for Education Statistics (1994). School library media centers in the United States 1990-91. Washington, D.C.: U.S. Department of Education, Office of Educational Research and Improvement.

Oberg, D. (1996). Principal support: What does it mean to teacher-librarians? In L. A. Clyde (Ed.) Sustaining the vision: A collection of articles and papers on research in school librarianship in honor of Jean E. Lowrie (pp. 221-230). Castle Rock, Colo.: Hi Willow Research.

Oberg, D., Hay, L., \& Henri, J. (2000). Role of the principal in the information literate school community: Cross country comparisons from an international research project. School Library Media Research [On-line] Available: http://www.ala.org/aasl/SLMR/ principal2/principal2.html [2001, March 6].

Pickard, P. W. (1993). The instructional consultant role of the school library media specialist. School Library Media Quarterly, 21, 115-121.

VanDuesen, J. D. (1996). The school library media specialist as a member of the teaching team: "Insider" and "Outsider." Journal of Curriculum and Supervision, 11 (3), 249-258.

VanDuesen, J. D. \& Tallman, J. (1994). The impact of scheduling on curriculum consultation and information literacy instruction. School Library Media Quarterly, 23, 1726.

Wilson, P., Blake, M., \& Lyders, J. (1999). Principals and teacher-librarians: A study and a plan for partnership. In K. Haycock (Ed.), Foundations for effective school library media programs (pp.271-278). Englewood, CO: Libraries Unlimited.

Zweizig, D. L. \& Hopkins, D. M. (Eds.) (1999). Lessons from Library Power: Enriching teaching and learning. Englewood, $\mathrm{CO}$ : Libraries Unlimited. 